\title{
Neuroprotective Role of Quercetin against Arsenic Induced Oxidative Stress in Rat Brain
}

\author{
Shveta Nirankari ${ }^{1}$, Rozy Kamal ${ }^{2}$ and Devinder K Dhawan ${ }^{1 *}$ \\ ${ }^{1}$ Department of Biophysics, Panjab University, Chandigarh, India \\ ${ }^{2}$ Centre for Nuclear Medicine, Panjab University, Chandigarh, India
}

\begin{abstract}
Arsenic, a poisonous metalloid, is ubiquitous in the environment, and affects nearly all organ systems of animals including humans The present study was conducted to understand the protective role of quercetin, a natural flavonoid on arsenic-induced oxidative damage in rat brain. Forty male Sprague Dawley rats, aged between 7 to 8 weeks and weighing 150-200 g were divided into four groups viz. normal control, arsenic treated, quercetin treated and arsenic + quercetin treated. Rats in normal control group were given normal food and drinking water. Rats in arsenic treated group were given arsenic daily in the form of sodium arsenite $\left(\mathrm{NaAsO}_{2}\right)$ in drinking water at a dose of $100 \mathrm{mg} / \mathrm{l}$. Rats in the quercetin treated group were given quercetin, dissolved in distilled water, orally everyday through intubation gavage at a dose of $50 \mathrm{mg} / \mathrm{kg}$ body weight. Rats in the combined arsenic + quercetin treated group were given arsenic and quercetin in a similar manner as was given to rats belonging to arsenic and quercetin treated group. After 2 months of treatment, antioxidant defense status and changes in the brain histo-architecture were assessed. A significant increase in the levels of lipid peroxidation and a decrease in reduced glutathione levels were observed in the brain of arsenic treated rats, when compared to the normal controls. Further, decrease in the activities of antioxidant defense enzymes such as superoxide dismutase, glutathione peroxidase, glutathione-s-transferase and glutathione reductase, as well as the activity of enzyme nitric oxide synthase were detected in arsenic treated group, which however were restored to normal levels upon simultaneous treatment with quercetin. Brain tissue of arsenic treated rats, also showed changes at the histo-architectural level which were normalized on simultaneous treatment with quercetin. The study, therefore, reveals that quercetin shall prove to be beneficial in containing the neuro-toxic effects of arsenic.
\end{abstract}

\section{Keywords: Arsenic; Quercetin; Cerebellum; Oxidative stress}

\section{Introduction}

Human exposure to arsenic is primarily a result of inhalation of metal particles in air, ingestion of contaminated food and through drinking water. Intake of inorganic arsenic over a long duration can lead to chronic arsenic poisoning (arsenicosis). It is known now that inorganic arsenic has toxic effects at both high and low levels of exposure. Chronic exposure to arsenic-contaminated water and food can have adverse effects on various organs that may lead to development of cancer in skin, liver, lung and bladder [1-5]. It is believed that damage due to arsenic is closely associated with oxidative stress induced by arsenic. As reported in earlier studies, arsenic is known to cause generation of free radicals, like reactive oxygen species (ROS) and reactive nitrogen species (RNS), as well as metabolic intermediates like dimethyl arsenic (DMA) peroxy radical [6-11].

Brain is one of the critical organs particularly susceptible to the damaging effects of ROS, as it has a limited capacity to detoxify ROS owing to low glutathione-producing capacity of neuronal cells [12], and also because of its high metabolic rate as well as relatively reduced capacity for cellular regeneration as compared to other organs. In addition, arsenic can easily cross the blood-brain barrier [13,14]; therefore making the brain highly susceptible to arsenic exposure and also to the resultant ROS induced oxidative stress.

Quercetin, a member of the flavonoids family, is ubiquitously present in food items including vegetables, fruits, tea and wine. It is a powerful antioxidant, which can prevent oxidative injury and cell death by chelating metal ions, scavenging oxygen radicals, and protecting against lipid peroxidation (LPO) [15]. With its chelating effect, quercetin scavenges free radicals, thereby preventing oxidative damage to DNA and also to cell membranes thus stabilizing lipid membranes by preventing LPO by free radicals $[16,17]$. Additionaly, quercetin is also known to decrease ROS production, increases both Mn SOD (manganese superoxide dismutase) activity and glutathione levels and also suppresses over-expression of the inducible form of nitric oxide synthase (iNOS).

An important property of quercetin which could be relevant with regard to its protective role in arsenic induced neurotoxicity is that, it is able to cross the blood brain barrier [18]. Therefore, quercetin could be a potent nutrient that can access the brain and may protect it from disorders associated with oxidative stress [19]. Since, brain damage due to arsenic is expected to be caused mainly by oxidative stress, so role of quercetin in such a condition needs to be explored. Therefore, the present study was designed to evaluate the protective role of quercetin, if any, during arsenic induced neurotoxicity.

\section{Material and Methods}

\section{Chemicals}

All the chemicals and reagents used in the present study were of reagent grade. Sodium arsenite $\left(\mathrm{NaAsO}_{2}\right)$ and quercetin were purchased from Sigma-Aldrich (USA). All other chemicals such as nicotinamide adenine dinucleotide phosphate (NADPH), bovine serum albumin (BSA), trichloroacetic acid (TCA), thiobarbituric acid (TBA), ethylene diamine tetra-acetic acid ( EDTA), Triton X-100, 5, 5'-Dithiobis-(2Nitrobenzoic Acid) (DTNB), 1-chloro-2, 4-dinitrobenzene (CDNB), reduced glutathione $(\mathrm{GSH})$, nitro blue tetrazolium chloride (NBT), glutathione reductase $(\mathrm{GR})$ and hydrogen peroxide $\left(\mathrm{H}_{2} \mathrm{O}_{2}\right)$, were purchased from Sisco Research Labs (India) and Hi-media chemicals (India).

${ }^{*}$ Corresponding author: D.K Dhawan, Professor, Department of Biophysics, Panjab University, Chandigarh, India, Tel: +91-9878253746; E-mail: dhawan@pu.ac.in

Received January 05, 2016; Accepted February 26, 2016; Published February 29, 2016

Citation: Nirankari S, Kamal R, Dhawan DK (2016) Neuroprotective Role of Quercetin against Arsenic Induced Oxidative Stress in Rat Brain. J Environ Anal Toxicol 6: 359. doi:10.4172/2161-0525.1000359

Copyright: (c 2016 Nirankari S, et al. This is an open-access article distributed under the terms of the Creative Commons Attribution License, which permits unrestricted use, distribution, and reproduction in any medium, provided the original author and source are credited. 


\section{Animals}

Healthy male Sprague Dawley (S.D.) rats in the weight range of 150-200 g were obtained from the central animal house of Punjab University, Chandigarh, India. The animals were housed in polypropylene cages under a hygienic bed of husk (regularly changed) in a well-ventilated animal room. Throughout the treatment period, the animals were provided with standard animal palliated feed obtained from Ashirwad Industries, Kharar, Punjab, India and were also provided with water ad libitum. Before treatment, the rats were acclimatized to experimental conditions for a period of one week. All the procedures were done in accordance with ethical guidelines for care and use of laboratory animals, which were approved by Institutional Animal Ethics Committee (IAEC), Punjab University Chandigarh, India.

\section{Grouping of animals}

Rats of age 7-8 weeks were segregated into following four groups and each group consisted of 10 animals. Animals in group I served as normal controls, and was given standard laboratory feed and water ad libitum throughout the period of experimentation. Group II animals were given arsenic daily in the form of $\mathrm{NaAsO}_{2}$ in drinking water at a dose of $100 \mathrm{mg} / \mathrm{L}$ [20]. The animals in Group III were given quercetin orally every day in drinking water through intubation gavage at a dose of $50 \mathrm{mg} / \mathrm{kg}$ body weight [19]. The animals in Group IV were given a combined treatment of arsenic as well as quercetin in a similar manner as was given to Group II and Group III animals, respectively. The study was carried out for a total duration of 2 months.

\section{Sample preparation}

After 2 months of treatment period, the animals from all the treatment groups were sacrificed using overdose of ether anesthesia. After dissection, the brains were immediately removed, washed in ice-cold isotonic saline and a small portion of the brain (cerebellum) was fixed in formalin saline (10\%) for histological examination using light microscope. The remaining cerebellar tissue was used to prepare the tissue homogenate. Tissue homogenates $(10 \% \mathrm{w} / \mathrm{v})$ were prepared in ice-cold $10 \mathrm{mM}$ phosphate-buffered saline (PBS), $0.15 \mathrm{M}$ sodium chloride $(\mathrm{NaCl}), \mathrm{pH}$ 7.4. The homogenates were centrifuged at 2000 $\mathrm{g}$ for $10 \mathrm{~min}$ at $4^{\circ} \mathrm{C}$ to obtain crude homogenates, which were free of cell debris and nuclear pellets. A fraction of the crude homogenate was then re-centrifuged at $10,000 \mathrm{~g}$ for $30 \mathrm{~min}$ at $4^{\circ} \mathrm{C}$, to obtain the postmitochondrial supernatants (PMS).Crude homogenates were used for LPO and reduced glutathione (GSH) estimation and PMS fractions were used to carry out the estimations of the remaining oxidative stress parameters namely, glutathione peroxidase (GPx), glutathione transferase (GST), glutathione reductase (GR), superoxide dismutase (SOD), iNOS and catalase.

\section{Lipid peroxidation (LPO)}

Lipid peroxidation was assayed by using the method of Wills, 1966 [21]. Briefly, $0.5 \mathrm{ml}$ of tissue homogenate was diluted to $1.0 \mathrm{ml}$ using Tris- $\mathrm{HCl}$ buffer $(0.1 \mathrm{M}, \mathrm{pH}$ 7.4). The reaction mixture was incubated at $37^{\circ} \mathrm{C}$ for $2 \mathrm{hrs}$ with constant shaking. At the end of the incubation, 1.0 $\mathrm{ml}$ of TCA $(10 \%, \mathrm{w} / \mathrm{v})$ was added and then after thorough mixing, the reaction mixture was centrifuged at 800 rotations per $\min (\mathrm{rpm})$ for 10 min. To $1.5 \mathrm{ml}$ supernatant, $1.5 \mathrm{ml}$ TBA $(0.67 \% \mathrm{w} / \mathrm{v})$ was added. Color was developed by placing the test tubes at $100^{\circ} \mathrm{C}$ for $10 \mathrm{~min}$ in a boiling water bath. The samples were cooled and diluted with $1.0 \mathrm{ml}$ distilled water. The optical density was recorded at a wavelength of $535 \mathrm{~nm}$. The results were expressed as nano moles of malonedialdehyde (MDA) formed $/ \mathrm{min} / \mathrm{mg}$ of protein.

\section{Glutathione peroxidase (GPx)}

GPx activity was measured by using method described by Paglia and Valentine's [22]. The reaction mixture contained $2.65 \mathrm{ml}$ of 50 $\mathrm{mmol} / \mathrm{l}$ phosphate buffer ( $\mathrm{pH}$ 7), $0.1 \mathrm{ml}$ of $150 \mathrm{mM}$ GSH solution, 0.1 $\mathrm{ml} \mathrm{GR}(10 \mathrm{mg} / \mathrm{ml}), 0.1 \mathrm{ml}$ of $3 \mathrm{mM}$ NADPH-Na salt, $0.1 \mathrm{ml} 50 \mathrm{mmol} / \mathrm{l}$ $\mathrm{H}_{2} \mathrm{O}_{2}$ solution and $0.02 \mathrm{ml}$ of tissue homogenate. The GPx activity was monitored as a decrease in absorbance due to the consumption of $\mathrm{NADPH}$, which absorbs at $340 \mathrm{~nm}$. The GPx activity was expressed as nano moles of NADPH consumed/min/mg protein using an extinction coefficient of $6.22 \times 10^{-3} \mathrm{mM}^{-1} \mathrm{~cm}^{-1}$.

\section{Reduced glutathione (GSH)}

GSH levels were determined according to the method of Ellman et al. [23]. $0.1 \mathrm{ml}$ of TCA was added to $500 \mu \mathrm{l}$ of tissue homogenate. After mixing the contents, the precipitated proteins were separated by centrifugation at $2000 \mathrm{x} \mathrm{g}$ for $15 \mathrm{~min} .500 \mu \mathrm{l}$ of the supernatant obtained, was diluted in a test tube to $1.0 \mathrm{ml}$ with sodium phosphate buffer. To this, $2.0 \mathrm{ml}$ of freshly prepared DTNB was added. The yellow color developed was read immediately at $412 \mathrm{~nm}$. The GSH contents were expressed in term of $\mu \mathrm{mol}$ of GSH/g tissue.

\section{Glutathione reductase (GR)}

GR activity was measured by continuous rate determination method using a UV spectrophotometer [24]. To $3 \mathrm{ml}$ cuvette, 2.6 $\mathrm{ml}$ of phosphate buffer, $0.15 \mathrm{ml}$ of NADPH and $0.15 \mathrm{ml}$ of oxidised glutathione (GSSG) were added. The reaction was initiated by the addition $0.2 \mathrm{ml}$ of sample to the cuvette and the decrease in absorbance at $340 \mathrm{~nm}$ was followed for $5 \mathrm{~min}$ at $25^{\circ} \mathrm{C}$. The enzyme activity was calculated using the molar coefficient for NADPH of $6.22 \times 10^{-3} \mathrm{mM}^{-1}$ $\mathrm{cm}^{-1}$ and was expressed as $\mu$ moles of NADPH oxidised $/ \mathrm{min} / \mathrm{mg}$ of protein.

\section{Glutathione-s-transferase (GST)}

The enzyme activity of GST was determined by using the method of Habig et al. [25].The sample buffer was prepared by mixing $650 \mu \mathrm{l}$ of phosphate buffer, $25 \mu \mathrm{l} \mathrm{CDNB}$ and $25 \mu \mathrm{l} \mathrm{GSH}$. To the above sample buffer, $10 \mu \mathrm{l}$ of tissue homogenate was added and the absorbance was measured at $340 \mathrm{~nm}$ for $3 \mathrm{~min}$. The activity was expressed as $\mu$ moles of CDNB conjugate formed $\mathrm{min}^{-1} \mathrm{mg}^{-1}$ of protein by using the extinction coefficient of $9.6 \mathrm{mM}^{-1} \mathrm{~cm}^{-1}$.

\section{Superoxide dismutase activity (SOD)}

Superoxide dismutase activity was estimated following the method of Kono [26] wherein, the reduction of NBT was inhibited by SOD and measured at $560 \mathrm{~nm}$. The reaction was initiated by addition of hydroxylamine hydrochloride to the reaction mixture containing NBT and PMF of brain homogenate. The results were expressed as units per mg of protein with one unit of enzyme defined as the amount of SOD required to inhibit the rate of reaction by $50 \%$.

\section{Catalase (CAT)}

Catalase activity was assessed by following the method of Luck $\mathrm{H}$ [27], whereby the breakdown of $\mathrm{H}_{2} \mathrm{O}_{2}$ was measured at $240 \mathrm{~nm}$. Briefly, the assay mixture consisted of $3 \mathrm{ml}$ of $\mathrm{H}_{2} \mathrm{O}_{2}$ phosphate buffer $(0.0125$ $\mathrm{M} ; \mathrm{H}_{2} \mathrm{O}_{2}$ ) and $0.05 \mathrm{ml} \mathrm{PMF}$ of brain homogenate. The change in the absorbance was observed at $240 \mathrm{~nm}$ as a result of $\mathrm{H}_{2} \mathrm{O}_{2}$ decomposition. The amount of $\mathrm{H}_{2} \mathrm{O}_{2}$ decomposed was calculated on the basis of molar coefficient of $\mathrm{H}_{2} \mathrm{O}_{2}\left(0.0394 \mathrm{M}^{-1} \mathrm{~cm}^{-1}\right)$ and the results were expressed as $\mu$ moles of $\mathrm{H}_{2} \mathrm{O}_{2}$ decomposed $/ \mathrm{min} / \mathrm{mg}$ protein. 


\section{Nitric oxide synthase (NOS)}

Nitric oxide synthase activity was determined in terms of nitric oxide (NO) production. The estimation was carried out by using the method of Radassi et al. [28]. NO production was estimated by measuring nitrite, a stable metabolic product of NO, using Griess reagent. To $0.10 \mathrm{ml}$ of tissue homogenates, $0.100 \mathrm{ml}$ of Griess reagent was added into the ELISA plate. The ELISA plate was then incubated in dark at $37^{\circ} \mathrm{C}$ for $30 \mathrm{~min}$. Pink color thus obtained was read at 540 $\mathrm{nm}$ on an ELISA plate reader. The amount of nitrite produced was determined by a standard curve prepared by using sodium nitrite as reference standard. Results were expressed as $\mathrm{nM}$ of nitrite/g tissue.

\section{Protein determination}

Protein content was determined by the method of Lowry et al. [29] by using bovine serum albumin as protein standard.

\section{Histological study}

For various histological studies, small sections of cerebellum from each of the normal control and treated animals were taken, washed in ice-cold $0.9 \% \mathrm{NaCl}$ and fixed in the buffered formalin for about 24 to 28 hours. After fixation, the tissues were dehydrated by using ascending grades of alcohol. Dehydrated tissue were embedded in paraffin wax $\left(58-60^{\circ} \mathrm{C}\right)$ after subjecting them to different treatments as described in the procedure by Pearse [30]. Tissue sections of 5-7 microns thickness were cut using microtome and were stained using $\mathrm{H} / \mathrm{E}$ stain [31] and viewed under light microscope for histological changes.

\section{Statistical Analysis}

The results of all the experiments conducted during the current study are depicted in the form of tables and figures represented as Mean \pm SD. The results of different treatments have been compared with normal controls. Additionally, the results obtained from arsenic treatment group were compared with combined arsenic+ quercetin treatment group. The statistical significance of the values has been determined by using analysis of variance (ANOVA), followed by Newman Keul's test. All statistical analyses were performed using SPSS 14 software. P values of less than and equal to $0.001,0.01$, and 0.05 were considered to indicate statistically significant differences.

\section{Results}

Arsenic treatment for a total duration of two months significantly increased ( $p \leq 0.01)$ the levels LPO in cerebellum as compared to normal control groups (Table 1). When arsenic treated rats were cotreated with quercetin, the MDA levels were observed to be within the normal range. Quercetin treatment when given to normal rats did not reveal any significant effect on lipid peroxidation.

A significant increase $(\mathrm{p} \leq 0.001)$ in the enzyme activity of catalase in cerebellum was observed after arsenic treatment when compared with normal control group (Table 2). Quercetin alone and combined arsenic + quercetin did not show any significant change in the enzyme activity of catalase when compared to normal control group. However, when catalase activity in combined arsenic + quercetin was compared with arsenic treated rats, a significant decrease $(\mathrm{p} \leq 0.001)$ was observed; thereby indicating that simultaneous treatment with quercetin brought the enzyme activity of catalase within normal limits. The activities of antioxidant enzymes SOD and GPx were found to be significantly decreased ( $p \leq 0.001$ in SOD; $p \leq 0.05$ in GPx) in brain after arsenic treatment when compared to normal controls (Table 2). Quercetin alone did not show any significant change in both SOD and GPx activities when compared to normal rats, however when coadministration to arsenic treated animals, a significantly increase
( $p \leq 0.001)$ in the SOD enzyme activity was observed when compared with arsenic treated group, although the activity was still significantly lower in comparison to normal group. Further, no significant change in the GPx activity was observed after combined arsenic + quercetin administration when compared to arsenic treated group.

As shown in Table 3, the enzyme activities of GST and GR were also decreased significantly ( $p \leq 0.001$ in GST and $p \leq 0.01$ in GR) after arsenic treatment when compared with normal control group. Combined arsenic + quercetin treatment, did not cause any significant change in the activities of GST or GR when compared to arsenic treated group. Both the enzyme activities in the combined treatment group were significantly lower than control levels. Also quercetin alone did not show any significant change in the activities of GST and GR when compared to normal rats. The GSH content was found to be significantly decreased $(\mathrm{p} \leq 0.01)$ after arsenic treatment when compared to normal control rats (Table 3). Quercetin alone and combined arsenic + quercetin did not show any significant change in GSH levels when compared to normal controls. However, combined arsenic + quercetin treatment significantly increased $(p \leq 0.05)$ the levels of GSH when compared to arsenic treated animals.

A significant reduction $(\mathrm{p} \leq 0.001)$ in the NOS activity was observed after arsenic treatment when compared to normal control group (Table 4). Quercetin alone did not show any significant change in the NOS activity when compared to normal rats. Interestingly, the combined arsenic + quercetin treatment significantly increased $(\mathrm{p} \leq 0.01)$ the NOS activity in brain when compared to arsenic treated rats.

As shown in the Figure 1, the tissue sections obtained from normal control rats showed normally nucleated neurons, glial cells and pyramidal cells arranged in several layers. Arsenic treated sections showed marked alterations in the histo-architecture of glial cells, which were enlarged showing nuclear pyknosis and moderate cytoplasmic vacuolization. Quercetin co-administration to arsenic treated rats, showed an appreciable improvement in the overall histo-architecture

\begin{tabular}{|c|c|}
\hline Groups & $\begin{array}{c}\text { LPO (nmol MDA formed/min/mg } \\
\text { protein) }\end{array}$ \\
\hline Normal control & $37.1 \pm 8.9$ \\
\hline Arsenic & $53.1 \pm 10.2^{\mathrm{y}}$ \\
\hline Quercetin & $29.7 \pm 7.3$ \\
\hline Arsenic + Quercetin & $30.5 \pm 7.8^{\mathrm{c}}$ \\
\hline
\end{tabular}

All the values are expressed as Means $\pm S . D ; n=6$ for each group.

${ }^{x} p \leq 0.05,{ }^{y} p \leq 0.01,{ }^{z} p \leq 0.001$ by Newman- Keuls test when the values are compared with normal control group.

${ }^{a} p \leq 0.05,{ }^{b} p \leq 0.01,{ }^{c} p \leq 0.001$ by Newman- Keuls test when the values of Arsenic + Quercetin treated group are compared with Arsenic treated group.

Table 1: Effect of quercetin on lipid peroxidation (LPO) in cerebellum of rats subjected to arsenic treatment.

\begin{tabular}{|c|c|c|c|}
\hline Groups & $\begin{array}{c}\text { Catalase }(\boldsymbol{\mu m o l} \\
\mathbf{H}_{\mathbf{2}} \mathbf{2} \text { decomposed/ } \\
\text { min/mg protein) }\end{array}$ & $\begin{array}{c}\text { SOD } \\
\text { (International } \\
\text { Units) }\end{array}$ & $\begin{array}{c}\text { GPx }(\boldsymbol{\mu m o l} / \mathbf{m i n} / \\
\mathbf{m g} \text { protein) }\end{array}$ \\
\hline Normal control & $0.06 \pm 0.02$ & $1.14 \pm 0.06$ & $3.68 \pm 0.6$ \\
\hline Arsenic & $0.22 \pm 0.02^{z}$ & $0.48 \pm 0.02^{z}$ & $2.50 \pm 0.5^{x}$ \\
\hline Quercetin & $0.08 \pm 0.02$ & $0.99 \pm 0.1$ & $3.00 \pm 0.4$ \\
\hline $\begin{array}{c}\text { Arsenic + } \\
\text { Quercetin }\end{array}$ & $0.06 \pm 0.01^{\mathrm{c}}$ & $0.93 \pm 0.1^{\mathrm{cc}}$ & $2.55 \pm 0.3^{\mathrm{y}}$ \\
\hline
\end{tabular}

All the values are expressed as Means \pm S.D; $n=6$ for each group.

${ }^{x} p \leq 0.05,{ }^{y} p \leq 0.01,{ }^{z} p \leq 0.001$ by Newman- Keuls test when the values are compared with normal control group.

${ }^{a} p \leq 0.05,{ }^{b} p \leq 0.01,{ }^{c} p \leq 0.001$ by Newman- Keuls test when the values of Arsenic + Quercetin treated group are compared with Arsenic treated group.

Table 2: Effect of quercetin on catalase (CAT), superoxide dismutase (SOD) and GPx activities in cerebellum of rats subjected to arsenic treatment. 


\begin{tabular}{|c|c|c|c|}
\hline Groups & $\begin{array}{c}\text { GST ( } \mu \text { mol } \\
\text { conjugate } \\
\text { formed/min/mg } \\
\text { protein) }\end{array}$ & $\begin{array}{l}\text { GSH ( } \mu \mathrm{mol} \text { of } \\
\text { GSH/g tissue) }\end{array}$ & $\begin{array}{c}\text { GR ( } \mu \mathrm{mol} \text { of } \\
\text { NADPH oxidized/ } \\
\text { min/mg protein) }\end{array}$ \\
\hline Normal control & $3.39 \pm 0.7$ & $10.20 \pm 0.6$ & $3.41 \pm 0.8$ \\
\hline Arsenic & $1.45 \pm 0.3^{2}$ & $7.94 \pm 0.7^{y}$ & $2.23 \pm 0.8^{y}$ \\
\hline Quercetin & $2.99 \pm 0.5$ & $10.20 \pm 0.1$ & $2.92 \pm 0.5$ \\
\hline Arsenic + Quercetin & $1.82 \pm 0.4^{z}$ & $9.60 \pm 0.2^{\mathrm{a}}$ & $2.65 \pm 0.6^{x}$ \\
\hline
\end{tabular}

All the values are expressed as Means \pm S.D; $n=6$ for each group. ${ }^{x} p \leq 0.05,{ }^{y} p \leq 0.01,{ }^{z} p \leq 0.001$ by Newman- Keuls test when the values are compared with normal control group.

${ }^{a} p \leq 0.05,{ }^{b} p \leq 0.01,{ }^{c} p \leq 0.001$ by Newman- Keuls test when the values of Arsenic + Quercetin treated group are compared with Arsenic treated group.

Table 3: Effect of quercetin on glutathione-s-transferase (GST), reduced glutathione $(\mathrm{GSH})$ and glutathione reductase $(\mathrm{GR})$ in cerebellum rats subjected to arsenic treatment.

\begin{tabular}{|c|c|}
\hline Groups & NOS (nM of nitrite/g tissue) \\
\hline Normal control & $52.6 \pm 12.8$ \\
\hline Arsenic & $19.0 \pm 2.9^{\mathrm{z}}$ \\
\hline Quercetin & $51.0 \pm 10$ \\
\hline Arsenic + Quercetin & $34.9 \pm 8.3^{\mathrm{yb}}$ \\
\hline
\end{tabular}

All the values are expressed as Means \pm S.D; $n=6$ for each treatment group. ${ }^{x} p \leq 0.05,{ }^{y} p \leq 0.01,{ }^{z} p \leq 0.001$ by Newman- Keuls test when the values are compared with normal control group.

${ }^{a} p \leq 0.05,{ }^{b} p \leq 0.01,{ }^{c} p \leq 0.001$ by Newman- Keuls test when the values of Arsenic + Quercetin treated group are compared with Arsenic treated group.

Table 4: Effect of quercetin on nitric oxide synthase activity in cerebellum of rats subjected to arsenic treatment.

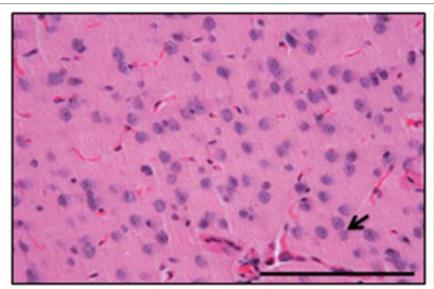

(A) Normal control

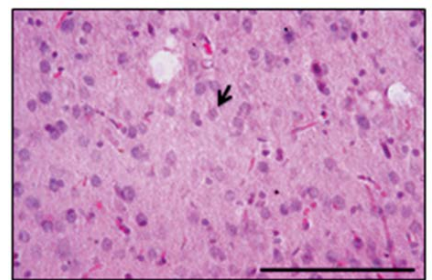

(C) Quercetin alone treated

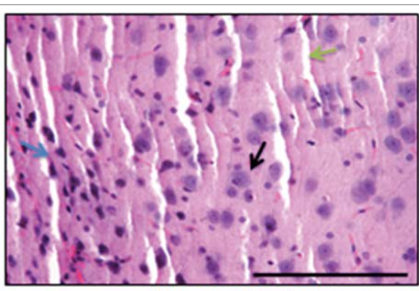

(B) Arsenic treated

(D) Arsenic + Quercetintreated

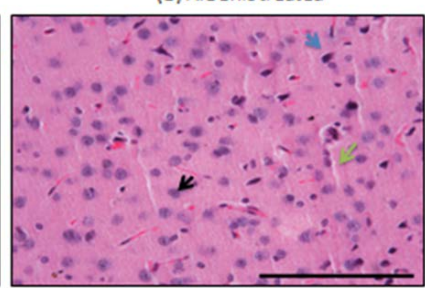

Figure 1: Photomicrographs of Normal Control, Arsenic, Quercetin and combined Arsenic + Quercetin treated rat brain (cerebellum), H \& E, 40X (A) Normal control rat showing normal nucleated neurons, glial cells (black arrows), pyramidal cells (B) Section of rat brain (cerebellum) treated with Arsenic alone showing enlarged glial cells (black arrows), nuclear pyknosis ( blue arrows) and moderate cytoplasmic vacuolization (green arrows) (C) Section of rat brain (cerebellum) treated with quercetin alone showing norma sized glial cells (black arrows), pyramidal cells. (D) Section of rat brain (cerebellum) treated with arsenic + quercetin showing normal sized glial cells (black arrows), pyramidal cells, mild pyknosis (blue arrows) and cytoplasmic vacuolization (green arrows).

of brain showing normal sized glial cells, pyramidal cells with mild pyknosis and cytoplasmic vacuolization.

\section{Discussion}

Enhanced oxidative stress has been suggested to be an important mechanism in arsenic-induced neurotoxicity [32]. In this study, we observed that chronic arsenic administration caused oxidative damage in the brain of arsenic treated rats which was assessed in terms of the activity of various antioxidant enzymes, level of LPO and by histological examination of stained brain tissue sections.

Lipid peroxidation is a vital marker for toxicity induced by various xenobiotics and is thought to be a consequence of oxidative stress initiated when the dynamic balance between peroxidant and antioxidant mechanism is impaired. Its significance lies in the fact that increases in the peroxidation of membrane lipids by the action of free radicals results in the loss of membrane integrity and function [33].

It has been demonstrated previously that arsenic treatment to animals increased the levels of LPO [34], even at low doses leading to apoptosis and necrosis of brain cells [35,36], suggesting cellular injury by action of free radicals. Therefore, increase in LPO observed in the present study following arsenic treatment to rats, could be a consequence of increased free radical production and/or consequent suppression in the activity of antioxidant defense enzymes and glutathione levels. In the present study, quercetin supplementation to arsenic treated rats proved to be beneficial as the levels of LPO in the combined group were found to be reduced when compared to arsenic alone treated group, thus demonstrating the protective role of quercetin in activating the antioxidant defense system in rat brain by preventing lipid peroxidation in cellular membranes.

Antioxidant enzymes such as SOD, catalase and GPx are the primary antioxidant enzymes, which help in degrading the toxic oxidative intermediates and are considered to be the first line of cellular defense against oxidative damage. Catalase is a haemo protein which reduces hydrogen peroxide to molecular oxygen and water. SOD is an antioxidant metallo enzyme that reduces superoxide radicals to water and molecular oxygen. SOD catalyzes the dismutation of superoxide radicals by scavenging free superoxide anions $\left(\mathrm{O}^{2-}\right)$. GPx uses GSH as a reducing substrate, and catalyzes the reduction of organic hydro peroxides [37-39].

Our results show that the activities of SOD and GPx in cerebellum region of brain decreased significantly following arsenic treatment. Decreased activity of SOD reflects suppression of the scavenging ability of SOD, which may be a result of accumulation of superoxide anion radical in the brain tissue post arsenic treatment. The suppressing action of arsenite on SOD activity was also demonstrated by Ramanathan et al. [40] in liver and kidney of male Wistar rats. Another report by Yamanaka et al. [41] suggested that free radical species are generated by the reaction of molecular oxygen with dimethyl arsine, a metabolite of dimethyl arsenic acid. They considered one of these radicals to be superoxide anion radical which is produced by one electron reduction of molecular oxygen by dimethyl arsine [42]. Similarly, catalase a detoxifying agent responds well to excess amount of $\mathrm{H}_{2} \mathrm{O}_{2}$ generated by the action of SOD. Catalase shares its function with GPx. Both these enzymes detoxify $\mathrm{H}_{2} \mathrm{O}_{2}$ but vary in their substrate affinities. As a matter of fact, $\mathrm{H}_{2} \mathrm{O}_{2}$ molecules are preferably metabolized by GPx because of its lower $\mathrm{km}$ for $\mathrm{H}_{2} \mathrm{O}_{2}$ than catalase, which is activated at comparatively higher conc. of $\mathrm{H}_{2} \mathrm{O}_{2}$. In the present study, catalase activity was found to be increased in brain tissue of rats following arsenic exposure, whereas GPx activity was suppressed suggesting that $\mathrm{H}_{2} \mathrm{O}_{2}$ production although increased following arsenic treatment, but was not high enough to suppress catalase activity, since only GPx activity was found to be suppressed and catalase was still activated.

Quercetin co-treatment along with arsenic normalized SOD and catalase activity in the combined treatment group. However, quercetin co-treatment could not normalize GPx activity probably because 
of direct effect of arsenic on its protein structure causing complete inhibition or loss of the enzyme activity. These results suggest that co-treatment with quercetin, helped maintain the balance between ROS production and antioxidant defense, as can be inferred from normalized antioxidant enzyme activity values in the combined treatment group. There are reports supporting the protective role of quercetin, against oxidative stress [43-45] whereby, quercetin, when administered at a dose of $50 \mathrm{mg} / \mathrm{kg}$ to rats, significantly increased SOD activity and decrease MDA level.

GSH, on the other hand, is an important water-phase antioxidant and an essential cofactor for antioxidant enzymes. It has facile electrondonating capacity, linked to its sulfhydryl (-SH) group that provides protection against mitochondrial damage by endogenous oxygen radicals. In the present study, a significant depletion in GSH level was observed following arsenic treatment when compared to normal rats. The decrease in GSH levels can be correlated to elevated levels of ROS in the arsenic treated rats, as GSH would be consumed in converting the unstable free radical species to stable ones. The other reason for GSH depletion could be the direct toxic effect of arsenic, since arsenic is known to form complexes with GSH (arsenic-GSH). These complexes are known to cross the blood-brain barrier easily [46] leading to oxidative damage and consequently apoptotic cell death. A decrease in $\mathrm{GSH}$ is known to trigger the activation of neuronal 1,2-lipoxygenase, which leads to the production of peroxides, an influx of calcium, and ultimately cell death [47].

GR is a crucial enzyme that reduces GSSG to the sulfhydryl form (GSH) by the NADPH-dependent mechanism. Decrease in GR activity after arsenic treatment when compared to normal rats as observed in the present study, which correlates with the decreased level of GSH, thereby indicating that arsenic toxicity suppressed the activity of GR, leading to decrements in GSH levels in brain and finally imbalance in redox status [48]. Quercetin supplementation alone did not show any significant change but prevented the decline in GR activity in combined treatment group. The neuroprotective activity of quercetin has been attributed to its antioxidant properties whereby quercetin is reported to trigger the activity of GR, which increases the overall GSH content, thus strengthening the antioxidant defense system [49].

GST is a natural antioxidant which catalyzes the conjugation of glutathione with various electrophiles and free ionic species produced from various toxins. Under oxidative stress, the excessive ROS induces an increase in GST levels, and then GST metabolizes the toxic products of lipid peroxidation, and other molecules [50]. In our study, a significant decrease in the GST activity was observed after arsenic treatment, which usually occurs under extreme oxidative stress conditions [6]. The reduced activity of GST is the consequence of oxidative modifications of proteins, or low glutathione levels. GST utilizes glutathione as a cofactor and therefore the decrease observed in its activity after acute arsenic exposure is suggested to come from the paucity of glutathione. However, quercetin supplementation alone, statistically did not show any significant change but prevented the decline in GST activity in the combined treatment group, thereby suggesting an increase in the antioxidant versus oxidant ratio which led to up-regulation of GST activity.

Nitric oxide is a signaling molecule in multicellular eukaryotic organisms, where it coordinates the function and interactions between cells of the cardiovascular, neuro, and immune system [51]. These cells have the ability to synthesize NO with the enzyme NOS using arginine and $\mathrm{O}_{2}$ as substrates [52]. Nitric oxide and L-citrulline are the principal products of NOS enzyme activity [53]. In our study, a significant decrease in iNOS enzyme activity was observed after arsenic treatment when compared to normal rats. It is known that the impairment of NO production is due to lower NOS protein levels, which results from decreased expression and/or increased degradation of the proteins. Previous studies reported a decrease in Ca-dependent NOS activity measured in vivo and in vitro in arsenic-exposed rats (37 ppm drinking water) with a decrease of nNOS protein levels and an increase in ROS generation and lipid peroxidation [54,55]. Quercetin supplementation to arsenic treated rats was able to increase the NOS enzyme activity in brain. Quercetin, a well-known $\mathrm{O}_{2}{ }^{--}$scavenger is also a NO scavenger [56], and therefore apparently less decrease as observed in the activity of NOS enzyme when quercetin is simultaneously administered along with arsenic, could be seen as a feedback mechanism to replenish the loss of NO induced by the scavenging action of quercetin.

Enhanced oxidative stress in the brain after arsenic exposure was reflected in histological observations where the tissue sections obtained from normal control rats showed normally nucleated neurons, glial cells and pyramidal cells arranged in several layers, whereas arsenic treated sections showed marked alterations in the histo-architecture of glial cells (enlarged glial cells), nuclear pyknosis and moderate cytoplasmic vacuolization; thereby suggesting that exposure to arsenic induces neuronal damage mediated by excessive generation of ROS. Similar results have been observed by Flora et al. [57] following arsenic exposure to rats. However, quercetin co-administration with arsenic showed an appreciable improvement in the overall histo-architecture of brain showing normal sized glial cells, pyramidal cells with mild pyknosis and cytoplasmic vacuolization.

\section{Conclusion}

The present study, therefore, concludes that quercetin as a prophylactic intervention could ameliorate the neurotoxicity action of arsenic by reducing oxidative stress.

\section{Acknowledgment}

The financial support of Department of Science and Technology (DST), New Delhi under PURSE Grant is gratefully acknowledged.

\section{References}

1. Schwartz RA (1997) Arsenic and the skin. Int J Dermatol 36: 241-250

2. Ferreccio C, González PC, Milosavjlevic SV, Marshall GG, Sancha AM (1998) Lung cancer and arsenic exposure in drinking water: a case-control study in northern Chile. Cad Saude Publica 14 Suppl 3: 193-198.

3. Smith AH, Goycolea M, Haque R, Biggs ML (1998) Marked increase in bladder and lung cancer mortality in a region of Northern Chile due to arsenic in drinking water. Am J Epidemiol 147: 660-669.

4. Steinmaus C, Moore L, Hopenhayn-Rich C, Biggs ML, Smith AH (2000) Arsenic in drinking water and bladder cancer. Cancer Invest 18: 174-182.

5. Chiou HY, Chiou ST, Hsu YH, Chou YL, Tseng CH, et al. (2001) Incidence of transitional cell carcinoma and arsenic in drinking water: a follow up study of 8 102 residents in an arseniasis-endemic area in northeastern Taiwan. Amer $\mathrm{J}$ Epidemiol 53: 411-418.

6. Bashir S, Sharma Y, Irshad M, Gupta SD, Dogra TD (2006) Arsenic-induced cell death in liver and brain of experimental rats. Basic Clin Pharmacol Toxicol 98: $38-43$.

7. Kumar A, Malhotra A, Nair P, Garg ML, Dhawan DK (2010) Protective role of zinc in ameliorating arsenic induced oxidative stress and histological changes in rat liver. J Environ Pathol Toxicol Oncol 29: 91-100.

8. Iwama K, Nakajo S, Aiuchi T, Nakaya K (2001) Apoptosis induced by arsenic trioxide in leukemia U937 cells is dependent on activation of p38, inactivation of ERK and the Ca2+-dependent production of superoxide. Int J Cancer 92: 518-526.

9. Liu SX, Athar M, Lippai I, Waldren C, Hei TK (2001) Induction of oxyradicals by arsenic: implication for mechanism of genotoxicity. Proc Natl Acad Sci U S A 98: 1643-1648. 
Citation: Nirankari S, Kamal R, Dhawan DK (2016) Neuroprotective Role of Quercetin against Arsenic Induced Oxidative Stress in Rat Brain. J Environ Anal Toxicol 6: 359. doi:10.4172/2161-0525.1000359

10. Wasserman GA, Liu X, Parvez F, Ahsan H, Factor-Litvak P et al. (2004) Water arsenic exposure and children's intellectual function in Araihazar, Bangladesh. Environ Health Perspect 112: 1329-1333.

11. Kumar A, Nair P, Malhotra A, Majumdar S, Garg ML, et al. (2011) Altered uptake and biological half-lives of $65 \mathrm{Zn}$ on arsenic exposure--modulation by zinc treatment. Biol Trace Elem Res 144: 1059-1068.

12. Shulman RG, Rothman DL, Behar KL, Hyder F (2004) Energetic basis of brain activity: implications for neuroimaging. Trends Neurosci 27: 489-495.

13. Rosado JL, Ronquillo D, Kordas K, Rojas O, Alatorre J, et al. (2007) Arsenic exposure and cognitive performance in Mexican schoolchildren. Environ Health Perspect 115: 1371-1375.

14. Piao F, Ma N, Hiraku Y, Murata M, Oikawa S, et al. (2005) Oxidative DNA damage in relation to neurotoxicity in the brain of mice exposed to arsenic at environmentally relevant levels. J Occup Health 47: 445-449.

15. Bu T, Mi Y, Zeng W, Zhang C (2011) Protective effect of quercetin on cadmiuminduced oxidative toxicity on germ cells in male mice. Anat Rec (Hoboken) 294 : 520-526.

16. Pratheepa Kumari R, Selvakumar K, Bavithra S, Zumaana R, Krishnamoorthy G, et al. (2011) Role of quercetin on PCBs (Aroclor-1254) induced impairment of dopaminergic receptor mRNA expression in cerebral cortex of adult male rats. Neurochem Res 36: 1344-1352.

17. Selvakumar K, Bavithra S, Krishnamoorthy G, Venkataraman P, Arunakaran J (2012) Polychlorinated biphenyls-induced oxidative stress on rat hippocampus: a neuroprotective role of quercetin. ScientificWorldJournal 2012: 980314.

18. Youdim KA, Qaiser MZ, Begley DJ, Rice-Evans CA, Abbott NJ (2004) Flavonoid permeability across an in situ model of the blood-brain barrier. Free Radic Bio Med 36: 592-604.

19. Ishisaka A, Ichikawa S, Sakakibara H, Piskula MK, Nakamura T, et al. (2011) Accumulation of orally administered quercetin in brain tissue and its antioxidative effects in rats. Free Radic Biol Med 51: 1329-1336.

20. Biswas R, Poddar S, Mukherjee A (2007) Investigation on the genotoxic effects of long-term administration of sodium arsenite in bone marrow and testicular cells in vivo using the comet assay. J Environ Pathol Toxicol Oncol 26: 29-37.

21. Wills ED (1966) Mechanisms of lipid peroxide formation in animal tissues. Biochem J 99: 667-676.

22. Paglia DE, Valentine WN (1967) Studies on the quantitative and qualitative characterization of erythrocyte glutathione peroxidase. J Lab Clin Med 70: 158-169.

23. Ellman GL (1959) Tissue sulfhydryl groups. Arch Biochem Biophys 82: 70-77.

24. Carlberg I, Mannervik B (1985) Glutathione reductase. Methods Enzymol 113 484-490

25. Habig WH, Pabst MJ, Jakoby WB (1974) Glutathione S-transferases. The first enzymatic step in mercapturic acid formation. J Biol Chem 249: 7130-7139.

26. Kono $Y$ (1978) Generation of superoxide radical during autoxidation of hydroxylamine and an assay for superoxide dismutase. Arch Biochem Biophys 186: 189-195.

27. Luck H (1971) In methods of enzymatic analysis Bergineyer HU (Eds) Academic Press, New York, pp 885-893.

28. Raddassi K, Berthon B, Petit JF, Lemaire G (1994) Role of calcium in the activation of mouse peritoneal macrophages: induction of NO synthase by calcium ionophores and thapsigargin. Cell Immunol 153: 443-455.

29. Lowry OH, Rosebrough NJ, Farr Al, Randall RJ (1951) Protein measurement with the Folin phenol reagent. J Biol Chem 193: 265-275.

30. Pearse AGE (1968) Histochemistry: Theoretical and Applied, $3^{\text {rd }}$ (Edn) J \& A Churchill, London, 1-759.

31. Humason GL (1962) Animal tissue techniques. San Francisco, CA Freeman WH and Company. Basic procedures-animal tissue technique 130-132.

32. Singh AP, Goel RK, Kaur T (2011) Mechanisms pertaining to arsenic toxicity. Toxicol Int 18: 87-93.

33. Flora SJ (2009) Structural, chemical and biological aspects of antioxidants for strategies against metal and metalloid exposure. Oxid Med Cell Longev 2: 191-206.

34. Tandon N, Roy M, Roy S, Gupta N (2012) Protective Effect of Psidium guajava in Arsenic-induced Oxidative Stress and Cytological Damage in Rats. Toxicol Int 19: 245-249.
35. Chaudhuri AN, Basu S, Chattopadhyay S, Das Gupta S (1999) Effect of high arsenic content in drinking water on rat brain. Indian J Biochem Biophys 36 51-54.

36. Chattopadhyay S, Bhaumik S, Nag Chaudhury A, Das Gupta S (2002) Arsenic induced changes in growth development and apoptosis in neonatal and adult brain cells in vivo and in tissue culture. Toxicol Lett 128: 73-84.

37. Das AK, Dewanjee S, Sahu R, Dua TK, Gangopadhyay M, et al. (2010) Protective effect of Corchorusolitorus leaves against arsenic-induced oxidative stress in rat brain. Food Chem Toxicol 48: 326-335.

38. Loschen G, Azzi A, Richter C, Flohé L (1974) Superoxide radicals as precursors of mitochondrial hydrogen peroxide. FEBS Lett 42: 68-72.

39. Ursini F, Maiorino M, Brigelius-Flohé R, Aumann KD, Roveri A, et al. (1995) Diversity of glutathione peroxidases. Methods Enzymol 252: 38-53.

40. Ramanathan K, Balakumar BS, Panneerselvam C (2002) Effects of ascorbic acid and alpha-tocopherol on arsenic-induced oxidative stress. Hum Exp Toxicol 21: 675-680.

41. Yamanaka K, Hoshino M, Okamoto M, Sawamura R, Hasegawa A, et al (1990) Induction of DNA damage by dimethylarsine, a metabolite of inorganic arsenics, is for the major part likely due to its peroxyl radical. Biochem Biophys Res Commun 168: 58-64.

42. Yamanaka K, Hasegawa A, Sawamura R, Okada S (1989) Dimethylated arsenics induce DNA strand breaks in lung via the production of active oxygen in mice. Biochem Biophys Res Commun 165: 43-50.

43. Emerit J, Edeas M, Bricaire F (2004) Neurodegenerative diseases and oxidative stress. Biomed Pharmacother 58: 39-46.

44. Connor DJ, Harrell LE, Jope RS (1989) Reversal of an aluminum-induced behavioral deficit by administration of deferoxamine. Behav Neurosci 103: 779-783.

45. Singh A, Naidu PS, Kulkarni SK (2003) Reversal of aging and chronic ethanolinduced cognitive dysfunction by quercetin a bioflavonoid. Free Radic Res 37 1245-1252.

46. Wang $Y$, Zhao $F$, Jin $Y$, Zhong $Y, Y u X$, et al (2011) Effects of exogenous glutathione on arsenic burden and NO metabolism in brain of mice exposed to arsenite through drinking water. Arch Toxicol 85: 177-184.

47. Schulz JB, Lindenau J, Seyfried J, Dichgans J (2000) Glutathione, oxidative stress and neurodegeneration. Eur J Biochem 267: 4904-4911.

48. Rodríguez VM, Del Razo LM, Limón-Pacheco JH, Giordano M, SánchezPeña LC, et al. (2005) Glutathione reductase inhibition and methylated arsenic distribution in Cd1 mice brain and liver. Toxicol Sci 84: 157-166.

49. Liu H, Zhang L, Shaoping L (2012) Evaluation of Antioxidant and Immunity Activities of Quercetin in Isoproterenol-Treated Rats. Molecules 17: 4281-4291.

50. Toyama T, Shinkai Y, Yasutake A, Uchida K, Yamamoto M, et al. (2011) Isothiocyanates reduce mercury accumulation via an Nrf2-dependent mechanism during exposure of mice to methyl mercury. Environ Health Perspect 119: 1117-1122.

51. Bredt DS, Snyder SH (1994) Nitric oxide: a physiologic messenger molecule. Annu Rev Biochem 63: 175-195.

52. Alderton WK, Cooper CE, Knowles RG (2001) Nitric oxide synthases: structure function and inhibition. Biochem J 357: 593-615.

53. Chinje EC, Stratford IJ (1997) Role of nitric oxide in growth of solid tumours: a balancing act. Essays Biochem 32: 61-72.

54. Zarazua S, Perez-Severiano F, Delgado JM, Martínez LM, Ortiz-Perez D, et al. (2006) Decreased nitric oxide production in the rat brain alters chronic arsenic exposure. Neurochem Res 31: 1069-1077.

55. Santoyo ME, Sepúlveda-Saavedra J, Zarazúa S, Pérez-Severiano F, RomeroDíaz V, et al. (2007) Neurochemical and morphological alterations in the rat brain associated with chronic arsenic exposure. In: Santamaría A, JiménezCapdeville ME (Eds) New Perspectives on Brain Damage, Neurodegeneration and Neuroprotective Strategies. Research Signpost, Kerala, India, 189-201.

56. Robak J, Gryglewski RJ (1988) Flavonoids are scavengers of superoxide anions. Biochem Pharmacol 37: 837-841.

57. Flora SJS, Dwivedi N, Deb U, Kushwaha P, Lomash V (2014) Effects of coexposure to arsenic and dichlorvos on glutathione metabolism, neurological hepatic variables and tissue histopathology in rats. Toxicol Res 3: 23-31. 